\title{
Measuring Acetabular Cup Orientation on Antero-Posterior Radiographs of the Hip after Total Hip Arthroplasty with a Vector Arithmetic Radiological Method. Is It Valid and Verified for Daily Clinical Practice?
}

\author{
Messung der Hüftpfannenposition auf anteroposterioren Beckenübersichtsauf- \\ nahmen nach Implantation einer Hüftendtotalendoprothese mittels vektor-arith- \\ metischer Methode. Wie genau ist dies im klinischen Alltag?
}

Authors

Affiliations
B. Craiovan ${ }^{1}$, M. Weber ${ }^{1}$, M. Worlicek ${ }^{1}$, M. Schneider ${ }^{1}$, H. R. Springorum ${ }^{1}$, F. Zeman ${ }^{2}$, J. Grifka' ${ }^{1}$, T. Renkawitz ${ }^{1}$

Orthopedic Surgery, University Medical Center Regensburg, Bad Abbach/Regensburg, Germany

Center for Clinical Studies, University Medical Center Regensburg, Germany

\author{
Key words \\ - total hip arthroplasty \\ - cup orientation \\ measurement \\ - error analysis \\ pelvic tilt
}

received $\quad 8.11 .2015$

accepted 14.2.2016

\section{Bibliography}

DOI http://dx.doi.org/ 10.1055/s-0042-104205

Published online: 19.4.2016

Fortschr Röntgenstr 2016; 188:

574-581 @ Georg Thieme

Verlag KG Stuttgart · New York . ISSN 1438-9029

\section{Correspondence}

Herr Dr. Benjamin Craiovan Orthopedic Surgery, University Medical Center Regensburg Kaiser-Karl-V-Alle 3 93077 Bad Abbach / Regensburg Germany

Tel.: ++49/9405180

Fax: ++49/9405182906

benjamin.craiovan@ukr.de

\section{Zusammenfassung \\ $\nabla$}

Ziel: Ziel dieser prospektiven Studie war es eine vektor-arithmetische Methode zur Messung der Hüftpfannenposition nach Implantation einer Hüfttotalendoprothese (Hüft-TEP) zu validieren und deren Genauigkeit für die Anwendung im klinischen Alltag zu überprüfen.

Material und Methoden: Die Pfannenanteversion und -inklination von 123 Patienten nach zementfreier primärer Hüft-TEP wurde zweimal von zwei verblindeten Untersuchern auf einer tiefen Beckenübersichtsaufnahmen im anteroposterioren (ap) Strahlengang mit einer vektor-arithmetischen Methode vermessen und anschließend mit den Werten einer 3D-CT-Referenzmessung durch ein externes Institut unter Berücksichtigung der radiologischen Definition verglichen.

Ergebnisse: Die mittlere Differenz zwischen der radiologischen und der 3D-CT-Messung betrug $-1,4^{\circ} \pm 3,9^{\circ}$ für die Inklination und $0,8^{\circ} \pm 7,9^{\circ}$ für die Anteversion. Die Pfanneninklination korrelierte sehr gut $(r=0,81, p<0,001)$ und die -anteversion gut $(r=0,65, p<0,001)$ mit den 3D-CT Werten. Der Intraclass-Korrelationskoeffizient für die Messung im Röntgen betrug 0.98 (95\%-CI: 0,98; 0,99) für den ersten und 0,94 (95\% -Cl: 0,92; 0,96) für den zweiten Untersucher. Die Interrater-Reliabilität betrug 0,96 (95\%-KI: 0,93; 0,98) für die Inklination und 0,93 (95\%-CI: 0,85; 0,96) für die Anteversion.

Schlussfolgerung: Die größten Messfehler traten bei einer außergewöhnlichen Beckenkippung in der Bildebene auf. Um eine verlässliche, dem CT vergleichbare, Bestimmung der Pfannenposition nach Hüft-TEP auf konventionellen Röntgenaufnahmen durch die vektor-arithmetische Methode zu erreichen, ist in Zukunft die Berücksichtigung der Beckenkippung notwendig.

Kernaussagen:

- Messungen der Pfannenposition nach Hüft-TEP auf einer tiefen Beckenübersichtsaufnahmen

\section{Abstract \\ $\nabla$}

Purpose: The aim of this prospective study is to validate a vector arithmetic method for measuring acetabular cup orientation after total hip arthroplasty (THA) and to verify the clinical practice.

Materials and Methods: We measured cup anteversion and inclination of 123 patients after cementless primary THA twice by two examiners on AP pelvic radiographs with a vector arithmetic method and compared with a 3D-CT based reconstruction model within the same radiographic coronal plane.

Results: The mean difference between the radiographic and the 3D-CT measurements was $-1.4^{\circ} \pm 3.9^{\circ}$ for inclination and $0.8^{\circ} \pm 7.9^{\circ}$ for anteversion with excellent correlation for inclination $(r=0.81, p<0.001)$ and moderate correlation for anteversion $(r=0.65, p<0.001)$. The intraclass correlation coefficient for measurements on radiographs ranged from 0.98 (95\%-CI: 0.98; 0.99) for the first observer to 0.94 (95\%-CI: 0.92 ; 0.96 ) for the second observer. The interrater reliability was 0.96 (95\%-CI: 0.93; 0.98) for inclination and 0.93 (95\%-CI: 0.85; 0.96) for anteversion.

Conclusion: The largest errors in measurements were associated with an extraordinary pelvic tilt. In order to get a valuable measurement for measuring cup position after THA on pelvic radiographs by this vector arithmetic method, there is a need for a correct postoperative ap view, with special regards to the pelvic tilt for the future.

Key points:

- Measuring acetabular cup orientation on anteroposterior radiographs of the hip after THA is a helpful procedure in everyday clinical practice as a first-line imaging modality

- CT remains the golden standard to accurately determine acetabular cup position.

- Future measuring on radiographs for cup orientation after THA should account for integra- 
im ap Röntgen sind im klinischen Alltag als First-Line-Modalität ein hilfreiches Verfahren.

- CT bleibt der Goldstandard, um die Pfannenposition für biomechanische Fragestellungen genau zu bestimmen.

$\checkmark$ Zukünftige Messungen der Pfannenposition nach Hüft-TEP auf tiefen Beckenübersichtsaufnahmen im ap Röntgen sollten die Beckenkippung in der frontalen Bildebene berücksichtigen, um die Messgenauigkeit zu erhöhen. tion of the pelvic tilt in order to maximize the measurement accuracy.

Citation Format:

- Craiovan B, Weber M, Worlicek M et al. Measuring Acetabular Cup Orientation on Antero-Posterior Radiographs of the Hip after Total Hip Arthroplasty with a Vector Arithmetic Radiological Method. Is It Valid and Verified for Daily Clinical Practice?. Fortschr Röntgenstr 2016; 188: 574-581

\section{Introduction}

A number of studies have demonstrated that both short- and long-term results after total hip arthroplasty (THA) are associated with component positioning [1, 2]. Mal-orientation of the acetabular cup is correlated with prosthetic impingement, dislocation, wear, osteolysis, and early prosthetic loosening [2 - 5]. Accurate assessment of cup orientation is therefore essential for an evaluation of the outcome after THA and is typically done on postoperative antero-posterior (AP) pelvis radiographs [6-10]. While plain pelvic radiographs are available in clinical practice, their accurate interpretation is subject to substantial error, if the individual pelvic tilt orientation is not taken into consideration with special regard to different physiological orientations, static, vertical and rotational alignment and to the orientation of the radiographic plate $[6,7]$. It is thus of special interest to develop improved methods to accurately measure the postoperative cup orientation on plain radiographs.

Generally, six different definitions are used to measure and report cup inclination and anteversion. Murray [11] originally defined the anatomic, operative, and radiographic inclination and anteversion. Usually the coronal plane is used for radiographic evaluations in daily clinical practice without accounting for pelvic tilt. The anterior pelvic plane (APP) is commonly used as a reference plane to measure cup position when evaluating 3D-CT scans for biomechanical questions as well as in computer-navigated THA $[2,6,12,13]$. For the coronal plane it is essential to consider the pelvic tilt whereas the APP is independent of the pelvic tilt. Since it has been shown that the APP deviates from the coronal plane in almost all patients, it is important to use the same reference plane when comparing cup measurements on radiographs and CT scans [14].

The aim of this study was to research the accuracy, reliability and reproducibility of a vector arithmetic method for measuring acetabular cup orientation on antero-posterior radiographs of the hip after THA compared to cup position on three-dimensional computed tomography (3D-CT) reconstructions.

\section{Materials and Methods \\ $\nabla$}

During a registered, prospective randomized controlled trial (DRKS00 000 739, German Clinical Trials Register) evaluating navigation for THA, we randomized patients for, with or without the use of navigation. This investigation was approved by the local ethics commission. The current study is a secondary analysis from this cohort $[2,15]$.

A consecutive series of 135 patients were enrolled in this single center study, 12 of whom had to be withdrawn. 4 withdrew their informed consent and refused further participation in the study, as well as the use of their data. In one patient, a different stem type was used owing to the specific anatomy of the individ- ual. In 7 patients, no postoperative CT scans were available. For this study, the 123 data sets of THA were included for final analysis. Characteristics of the study group are shown in Table 1.

After written consent was received, THA was performed by four experienced orthopedic surgeons of the Department of Orthopedic Surgery, Regensburg University Medical Center. All had performed more than 200 THAs per year. All operations were performed in the lateral decubitus position through a minimally invasive (MicroHip ${ }^{\circledR}$ ) approach [16]. Press-fit components (Pinnacle, DePuy, Warsaw, Indiana), and cement-free hydroxyapatite-coated stems (Corail; DePuy, Warsaw, Indiana) were used. The tribological pairing consisted of polyethylene liners and metal heads with a diameter of $32 \mathrm{~mm}$. Following the hospital's standard, each patient had a standard two-dimensional AP pelvic radiograph in standing position one week postoperatively. In addition, an axial radiograph of the operated hip was taken. At a mean of six weeks (five to seven) post-operatively, pelvic and femoral computed tomography (CT) scans were performed (Somatom Sensation 16; Siemens, Erlangen, Germany).

CT-based calculation of the acetabular cup inclination and cup anteversion with 3D-CT image processing software

The position of the acetabular component was evaluated by an independent external institute (MeVis, Bremen, Germany) blinded to individual patient data. Segmentation was performed on the pelvic bone. The APP was extracted from the post-operative CT using $3 \mathrm{D}$ image processing software (MeVisLab, Bremen, Germany). The normal vector of the sagittal plane is identical to the vector between both anterior superior iliac spine landmarks. To construct the transverse plane, the center point of the pubic tubercle landmarks was projected onto the vector between both anterior superior iliac spine landmarks. The vector from the center point to its projection was used to determine the normal vector of the transverse plane. The normal vector of the coronal plane was calculated as the cross product of the sagittal and transverse normal vectors. Subsequently, a plane parallel to the implant aperture was constructed. Its normal vector represents the implant axis. Cup inclination and anteversion angles were calculated with respect to the APP ( $\bullet$ Fig. 1 ). The cup position was measured twice by two independent examiners, thus yielding four measurements. Radiographic inclination and anteversion according to Murray's definitions were calculated $[11,16]$. For comparability with the radiographs, the 3D-CT based cup inclination and anteversion were converted from APP to radiographic coronal plane using the pelvic tilt as described by Wan et al. [17]. Pelvic tilt was determined as the angle between APP and the radiographic coronal plane in a supine position [17]. 
Radiographic calculation of the acetabular cup inclination and cup anteversion from a post-operative AP radiograph using a vector arithmetic method

Based on postoperative AP pelvic digital radiograph (focus-film distance: $1150 \mathrm{~mm}$ ), both cup inclination and anteversion were measured using planning software with a vector arithmetic method (modiCAS||plan, 4 Plus GmbH, Erlangen, Bavaria, Germany, Version 2.2.3, 2014) with respect to the radiographic coronal plane according to the definition of Murray. The specific calibration of the radiograph was scaled in the acetabular region by

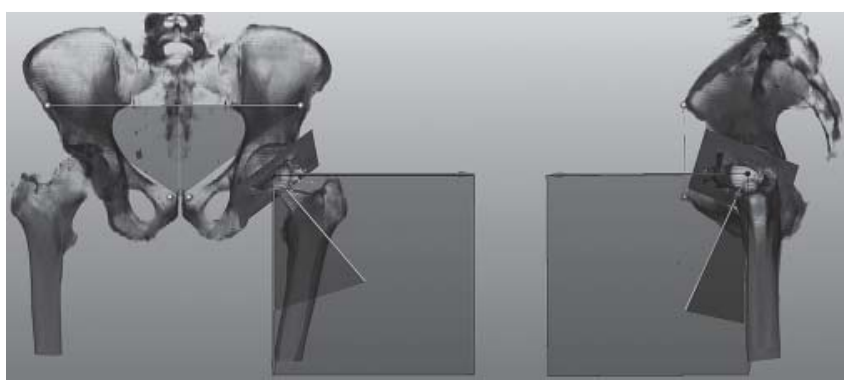

Fig. 1 The $3 \mathrm{D}$ surface model was interactively segmented using the image-processing software developed by MeVis for measuring inclination and anteversion from a post-operative CT scan.

Abb. 1 Das 3D-Oberflächenmodell wurde mit der MeVis Bildverarbeitungssoftware dreidimensional segmentiert um Inklination und Anteversion in postoperativen CT-Scans zu messen. using the prosthetic head size (diameter: $32 \mathrm{~mm}$ ), so magnification was corrected. As a reference plane for inclination measurements, we used the biischial line [10]. A special feature of the planning software is that the implants are shown as semi-transparent $3 \mathrm{D}$ CAD models. The position and orientation of the $3 \mathrm{D}$ CAD model of the cup implant in the respective size are changed in $3 \mathrm{D}$ space for inclination and anteversion until congruence is reached with the actual implant on the postoperative pelvic radiograph. The planning software refers to a vector arithmetic method measuring the angle with respect to the reference plane directly on the 3D CAD model ( $\bullet$ Fig. 2 ). The changing angle of anteversion and inclination of the acetabular 3 D CAD model of the cup implant model orientation can then be read out in degrees on the screen. This is with respect to the reference biischial line for inclination measurement and to the reference coronal plane for anteversion.

Two orthopedic surgeons, one arthroplasty fellow [MW] and one senior surgeon $[\mathrm{BC}]$, performed the measurements on plain AP pelvis radiographs, including a repetition of the procedure after a six-week interval. The observers were blinded to the 3D-CT and to each other's results.

According to Murray's definition, anteversion and inclination have been defined as radiographic, operative, and anatomic [11]. In our analysis we used the radiographic definition to measure inclination and anteversion on plain AP radiographs within the coronal plane.

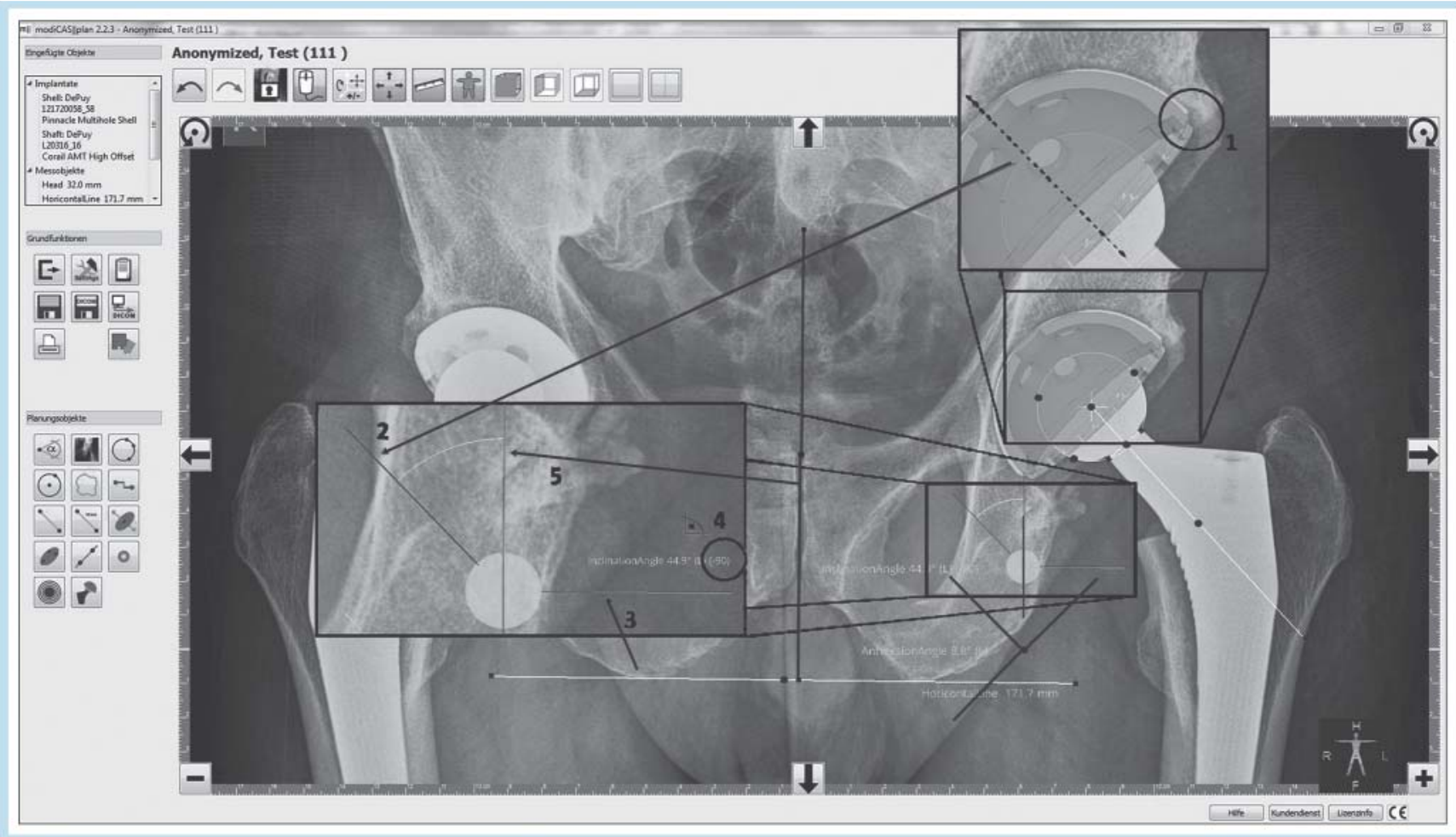

Fig. 2 In the postoperative AP radiograph, the chronological order is displayed for determination of the cup orientation with planning software called modiCASI I plan. The semitransparent CAD files of the cup implant model are superimposed on the pictured cup in the radiograph (1). The angle of inclination (2) with respect to the biischial line (3) and the angle of inclination (4) with respect to the coronal plane (5) are determined.
Abb.2 In dem postoperativen ap Röntgenbild ist die Reihenfolge der Schritte dargestellt, mit der die Pfannenposition unter Verwendung der Planungssoftware modiCASI I plan bestimmt wird. Es werden semitransparente CAD-Daten des jeweiligen farbigen Pfannenmodells zur Deckungsgleichheit mit der im Röntgen abgebildeten Pfanne gebracht (1). Dabei werden die Winkel für Inklination (2) bezogen auf die biischial line (3) und Anteversion (4) bezogen auf die Coronalebene (5) abgelesen. 


\section{Statistical methods}

$\nabla$

Statistical analyses were performed with IBM SPSS Statistics ${ }^{\circledR}$ 21.0 (SPSS Inc., Chicago, IL, USA) and R version 3.0.3. Data are presented as mean, standard deviation and range. The Pearson correlation coefficient was used to investigate the relationship between both measurement techniques. The level of significance was set at $\mathrm{p}<0.05$. Pearson's correlation coefficient was characterized as poor ( 0.00 to 0.20$)$, fair $(0.21$ to 0.40$)$, moderate $(0.41$ to 0.60$)$, good ( 0.61 to 0.80 ) or excellent ( 0.81 to 1.00 ) [18]. The graphical Bland-Altman analysis [19] was used for both parameters to detect potential systematic errors in the method by plotting the difference between the two measurement techniques of AP pelvis radiographs versus postoperative 3D-CT-based measurements against their averages. Intra- and inter-rater agreement was assessed by the intraclass correlation coefficient (ICC).

\section{Results}

$\nabla$

\section{Accuracy}

The mean difference between the measurement on pelvic plain radiographs and the $3 \mathrm{D}-\mathrm{CT}$-based measurements (3D-CT) was $1.4^{\circ}\left(\mathrm{SD} \pm 3.9^{\circ} ; 95 \% \mathrm{Cl}\right.$ of mean $-2.1^{\circ}$ to $-0.8^{\circ}$ ) for inclination and $0.8^{\circ}\left(\mathrm{SD} \pm 7.9^{\circ} ; 95 \% \mathrm{CI}\right.$ of mean $-0.5^{\circ}$ to $2.1^{\circ}$ ) for anteversion ( $\bullet$ Table 2). The Bland-Altman approach ( $\bullet$ Fig. 3) was used to illustrate agreement of both evaluation methods by plotting the individual differences of the two measurements on the vertical

Table 1 Demographic data.

Tab. 1 Demografische Daten.

\begin{tabular}{|lr|}
\hline \multicolumn{2}{|l|}{ characteristics } \\
\hline number of cases included & 123 \\
\hline mean age (range; StD) & $62.6(50$ to 75$) ; 7.7)$ \\
\hline gender (male/female) & $66 / 57$ \\
\hline side (right/left) & $67 / 56$ \\
\hline ASA & $2.1(0.7)$ \\
\hline mean BMI (range; StD) & $27.1(19.1$ to $42.7 ; 4.2)$ \\
\hline
\end{tabular}

ASA: American Society of Anesthesiologists; BMI: body mass index. axis against the mean of both measurements on the horizontal axis. The dashed lines in the graph represent the $95 \%$ limits of agreement (mean $\pm 1.96 \mathrm{SD}$ ). Therefore, it can be expected that $95 \%$ of the individual differences between the radiograph and the $3 \mathrm{D}-\mathrm{CT}$ are located in an interval of $6.1^{\circ}$ to $-8.9^{\circ}$ for inclination and $16.4^{\circ}$ to $-14.8^{\circ}$ for anteversion. Discrepancy between radiographic and 3D-CT measurements does not considerably increase with the averages of both methods and no systematic clusters of examiner values are obvious from the graphs. No systematic error was detected for the CT measurement methods as the means of the measurement pairs were spread evenly and randomly for both inclination and anteversion ( $\bullet$ Fig. 3 ).

Researching reasons for outliers, we found a difference between $3 \mathrm{D}-\mathrm{CT}$ and radiographic measurements of more than $10^{\circ}$ in anteversion in $71.4 \%(10 / 14)$ of patients with a pelvic tilt over $10^{\circ}$ (৫ Fig. 4).

The measurements from the plain radiographs using the vector arithmetic measurement technique showed excellent correlation for inclination $(\mathrm{r}=0.81, \mathrm{p}<0.001)$ and moderate correlation for anteversion $(r=0.65, p<0.001)$ when compared to the 3D-CT analysis (CT) ( $\bullet$ Fig. 5).

\section{Reliability}

All measurements on plain radiographs had an excellent intraand inter-rater-reliability ( $\bullet$ Table 3 ). The intraclass correlation coefficient (ICC) for measurements of inclination was 0.98 (95\%CI: 0.98; 0.99) for the first observer (MW) and 0.94 (95\%-CI: 0.92 ; 0.96) for the second observer (BC). The ICC for measurements of anteversion was 0.99 (95\%-CI: $0.98 ; 0.99)$ for the first observer (MW) and 0.95 (95\%-CI: 0.94; 0.97) for the second observer (BC). The inter-rater reliability for anteversion was 0.93 (95\%-CI: $0.85 ; 0.96)$ and 0.96 (95\%-CI: 0.93; 0.98) for inclination, respectively.

\section{Discussion}

In this study, we evaluated the accuracy, reliability and reproducibility of a vector arithmetic radiological method for measuring acetabular cup orientation on antero-posterior radiographs of

Table 2 Results of 3D-CT and radiographic inclination and anteversion measurements twice by two observers (in degree $=\circ$ ) for the coronal plane.

Tab. 2 Messergebnisse für Inklination und Anteversion im ap Röntgen und im 3D-CT zweimal gemessen durch zwei Untersucher (in Grad = o) in der Frontalebene.

\begin{tabular}{|c|c|c|c|c|c|c|c|c|}
\hline \multicolumn{4}{|c|}{ values for cup version } & \multicolumn{5}{|c|}{ difference 3D-CT to pelvic radiograph } \\
\hline & & \multirow{2}{*}{$\begin{array}{l}\text { 3D-CT } \\
\text { all meas }\end{array}$} & \multirow{2}{*}{$\begin{array}{l}\text { radiograph } \\
\text { all meas }\end{array}$} & \multicolumn{2}{|l|}{ observer 1} & \multicolumn{2}{|l|}{ observer 2} & \multirow{2}{*}{$\begin{array}{l}\text { observer } 1+2 \\
\text { all meas }\end{array}$} \\
\hline & & & & meas 1 & meas 2 & meas 1 & meas2 & \\
\hline \multirow[t]{3}{*}{$\begin{array}{l}\text { inclina- } \\
\text { tion }\end{array}$} & $\begin{array}{l}\text { mean } \\
(S D)\end{array}$ & $43.8(6.6)$ & $45.2(13.9)$ & $-1.9(4.1)$ & $-1.5(3.9)$ & $-1.7(4.2)$ & $-0.5(3.6)$ & $-1.4(3.9)$ \\
\hline & $\begin{array}{l}\text { range min; } \\
\max \end{array}$ & 26.4 to 66.4 & 0 to 61.7 & $-11.0 ; 16.7$ & $-10.4 ; 16.8$ & $-11.0 ; 18.7$ & $-8.1 ; 18.4$ & $-9.8 ; 17.6$ \\
\hline & $95 \% \mathrm{Cl}$ & 51.6 to 58.6 & 53.3 to 53.6 & $-10.0 ; 6.1$ & $-9.1 ; 6.0$ & $-10.1 ; 6.6$ & $-7.6 ; 6.6$ & $-8.9 ; 6.1$ \\
\hline \multirow[t]{3}{*}{$\begin{array}{l}\text { Ante- } \\
\text { version }\end{array}$} & $\begin{array}{l}\text { Mean } \\
(\mathrm{SD})\end{array}$ & $20.7(10.5)$ & $19.5(8.8)$ & $1.4(8,5)$ & $1.5(7.9)$ & $-0.2(8.30)$ & $0,6(7.7)$ & $0.8(7.9)$ \\
\hline & $\begin{array}{l}\text { range min; } \\
\max \end{array}$ & -14.9 to 49.8 & 0.0 to 39.7 & $-27.6 ; 24.7$ & $-26.6 ; 23.8$ & $-29.1 ; 22.3$ & $-27.2 ; 19.0$ & $-27.6 ; 22.1$ \\
\hline & $95 \% \mathrm{Cl}$ & -24.4 to 46.1 & 23.0 to 36.2 & $-15.3 ; 18.0$ & $-14.1 ; 17.0$ & $-16.5 ; 15.9$ & $-14.6 ; 15.7$ & $-14.8 ; 16.4$ \\
\hline
\end{tabular}

3D-CT: three-dimensional computed tomography; meas: radiographic measurement (= radiologische Messung); Cl: confidence interval of individual measurements (= Konfidenzintervall); Obs: Observer (= Untersucher). 


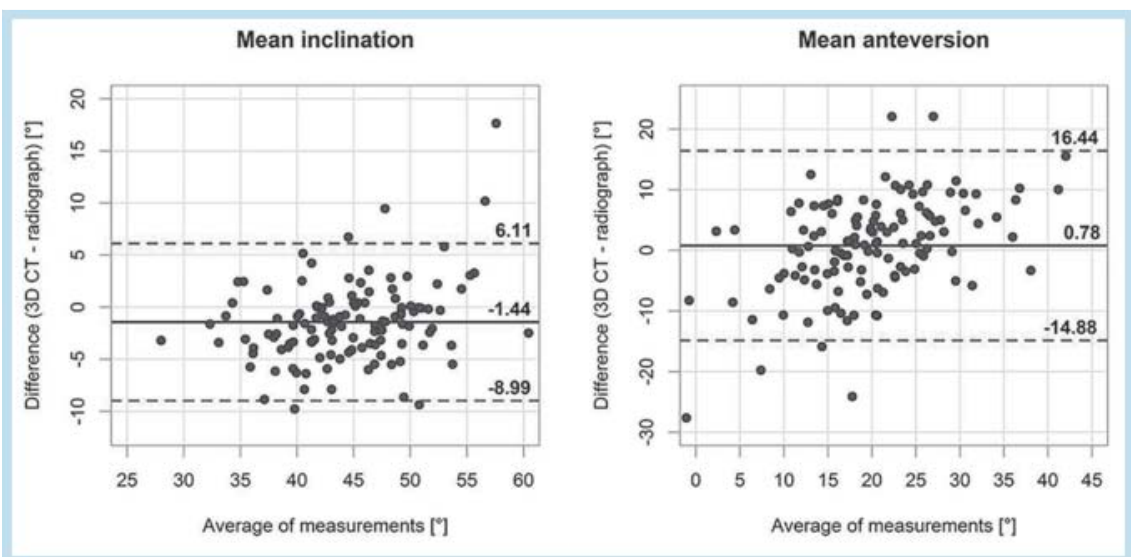

Fig. 3 The Bland-Altman plots show the mean differences between radiographic and 3D-CT measurements for inclination and anteversion. The straight blue line represents the mean value of all differences between the pairs of measurements, and the dashed red lines above and below represent the $95 \%$ limits of expectable individual agreement (mean +/- 1.96 SD). The means of the measurements were spread evenly and randomly for inclination and anteversion.
Abb. 3 Die Bland-Altman-Diagramme zeigen die mittleren Differenzen zwischen den radiologischen und 3D-CT-Messungen für die Inklination und Anteversion. Die gerade blaue Linie stellt den Mittelwert aller Unterschiede zwischen den Messpaaren dar. Die gestrichelte rote Linien umfasst die $95 \%$ Intervallgrenzen (Mittelwert +/- 1.96 SD). Die Mittelwerte der Messungen für die Inklination und Anteversion sind gleichmäßig und zufällig verteilt.
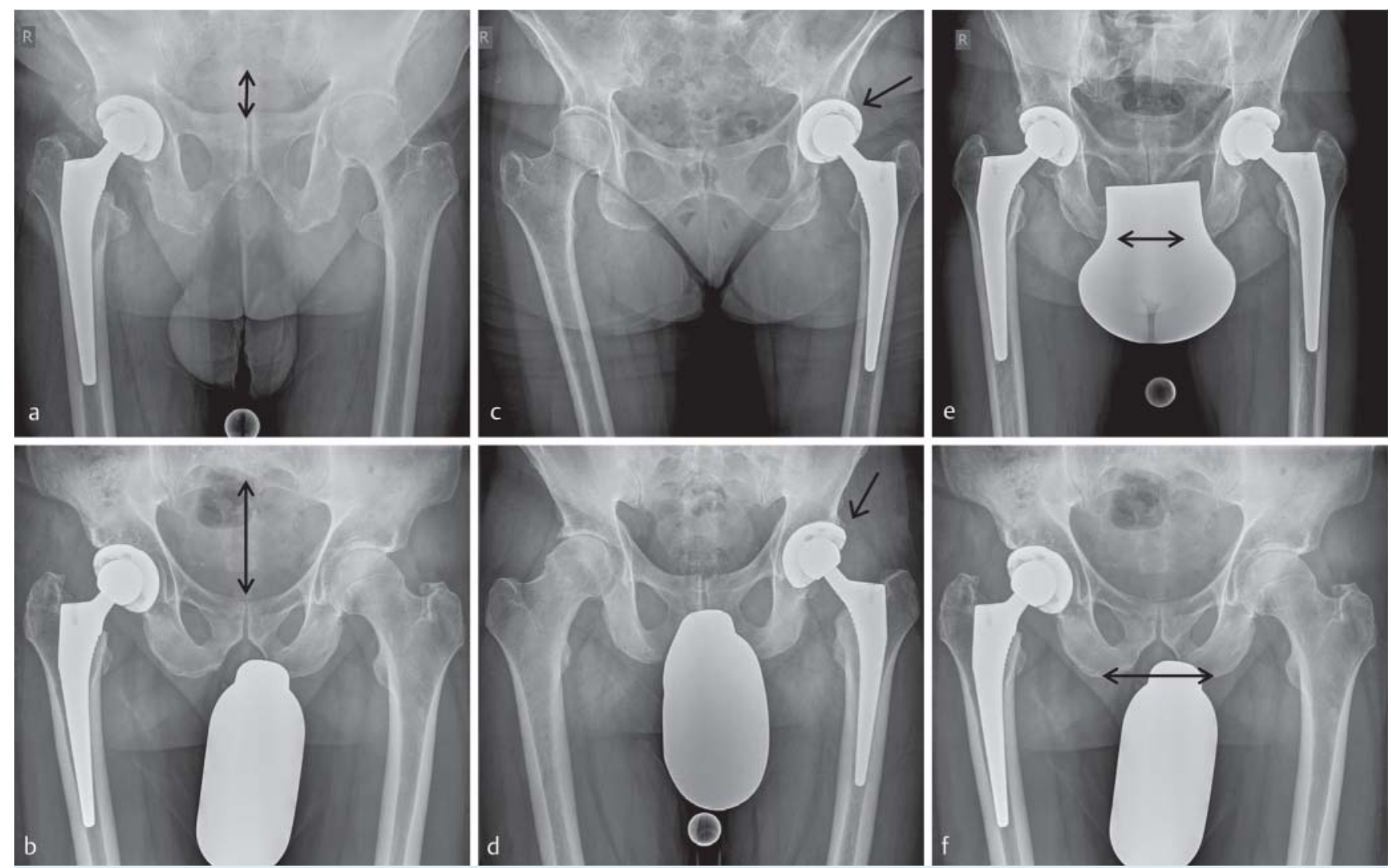

Fig. 4 :Reasons for outliers in the determination and measurement of inclination and anteversion. $\mathbf{a}, \mathbf{b}$ a greater tilt leads to outliers in anteversion measurement compared with low tilt; $\mathbf{c}, \mathbf{d}$ a greater anteversion leads to difficulties in exact determination of the inclination as the cup corner contour is more difficult to locate; $\mathbf{e}, \mathbf{f}$ the biischial line is not always visible. This leads to inaccuracy in reference plane determination for inclination measurement.
Abb. 4 Gründe für Ausreißer bei der Ermittlung und Messung der Inklination und Anteversion. $\mathbf{a}, \mathbf{b}$ eine größere Beckenkippung nach vorne in der Bildebene führt zu Ausreißern in der Anteversionsmessung im Vergleich zu einer geringen; $\mathbf{c}, \mathbf{d}$ eine größere Anteversion führt zu Schwierigkeiten bei der exakten Bestimmung der Inklination, da die Pfanneneckkontur schwieriger zu lokalisieren ist; $\mathbf{e}, \mathbf{f}$ Die Verbindungslinie der beiden Tuberositates ischiadicae ist nicht immer sichtbar, dies führt zu Ungenauigkeiten in der Bestimmung der Bezugsebene für die Messung der Inklination. 

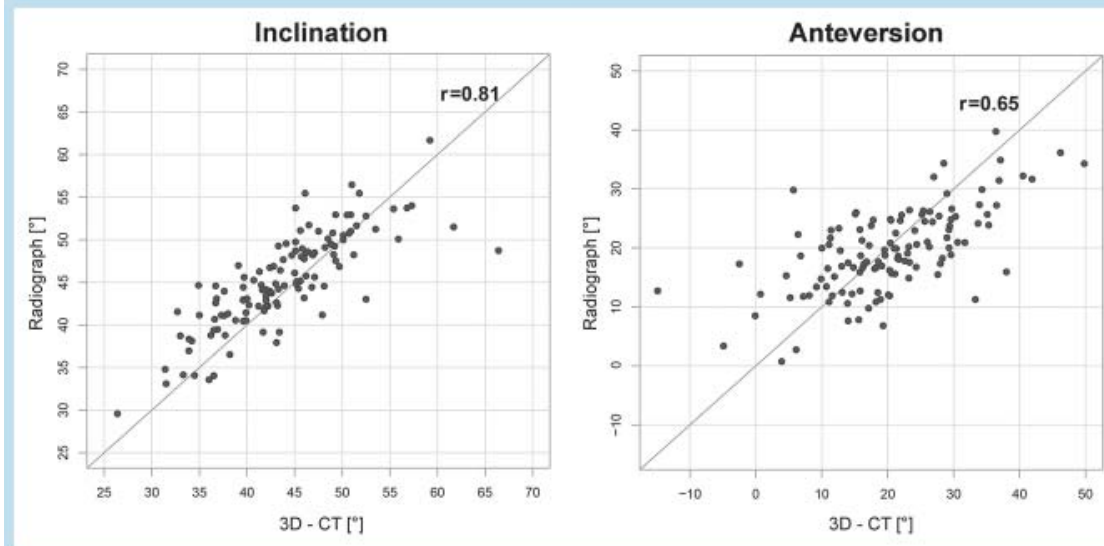

Fig. 5 Correlation between mean inclination and anteversion measurements of radiographs and 3DCT (displayed in degrees).

Abb.5 Korrelation zwischen den mittleren Inklinations- und Anteversionsmessungen zwischen Röntgenaufnahme und 3D-CT (dargestellt in Grad)

Table 3 Intra-and inter-rater reliability of measurements on plain pelvic radiographs (ICC: intra- class correlation coefficient; $\mathrm{Cl}$ : confidence interval).

Tab. 3 Intra- und interrater Reliabilität der Messungen im Röntgen tiefer Beckenübersichtsaufnahmen.

\begin{tabular}{|c|c|c|c|c|c|}
\hline $\begin{array}{l}\text { method } \\
\text { on }\end{array}$ & observer & \multicolumn{2}{|c|}{$\begin{array}{l}\text { intra-observer } \\
\text { reliability }\end{array}$} & \multicolumn{2}{|c|}{$\begin{array}{l}\text { inter-observer } \\
\text { reliability }\end{array}$} \\
\hline $\begin{array}{l}\text { AP radio- } \\
\text { graph }\end{array}$ & & ICC & $95 \% \mathrm{Cl}$ & ICC & $95 \% \mathrm{Cl}$ \\
\hline \multicolumn{6}{|c|}{ inclination } \\
\hline $\begin{array}{l}\text { vector } \\
\text { arith- } \\
\text { metic }\end{array}$ & observer 1 & 0.98 & $\begin{array}{l}0.98 \text { to } \\
0.99\end{array}$ & 0.96 & $\begin{array}{l}0.93 \text { to } \\
0.98\end{array}$ \\
\hline method & observer 2 & 0.94 & $\begin{array}{l}0.9^{\prime \prime} \text { to } \\
0.96\end{array}$ & & \\
\hline \multicolumn{6}{|c|}{ anteversion } \\
\hline $\begin{array}{l}\text { vector } \\
\text { arith- } \\
\text { metic }\end{array}$ & observer 1 & 0.98 & $\begin{array}{l}0.98 \text { to } \\
0.990: 93\end{array}$ & 0.93 & $\begin{array}{l}0.85 \text { to } \\
0.96\end{array}$ \\
\hline method & observer 2 & 0.95 & $\begin{array}{l}0.94 \text { to } \\
0.97\end{array}$ & & \\
\hline
\end{tabular}

3D-CT: three-dimensional computed tomography; meas: radiographic measurement; $\mathrm{Cl}$ : confidence interval of individual measurements

the hip after THA compared to measurements of cup orientation on $3 \mathrm{D}-\mathrm{CT}$ reconstructions of the pelvis.

We acknowledge several limitations of our study. First, only one type of press-fit cup was used. Therefore, different implant designs, i. e., oval or aspherical cups, may vary regarding their characteristics of radiographic measurement. Second, deviations of the central beam from the symphysis center to the acetabular cup were not considered in our radiographic measurement. However, this is a general limitation of ap radiographs and is not specifically related to our novel technique [20]. Third, inaccuracies during the prosthesis segmentation process for the 3D-CT reconstruction model could contribute to differences between radiographic and CT measurements.

On the one hand, the quality measurement tool on the ap plain pelvic view is a static observation. Here, the following aspects should be considered. Radiographs usually refer to the coronal plane in a standing position while CTs refer to the APP in a supine position. In this study we converted the CT scans in a lying position with the help of measuring pelvic tilt and a correction factor as published by Wan et al. to the radiographic coronal plane in a standing position [17]. Different authors have shown that a sub- stantial error of up to 10 degrees in measuring cup position can occur, if the same reference plane is not taken into consideration [17]. Furthermore, while Babisch et al. found no relevant difference between the supine and standing position, Eilander et al. found in most patients a small reclination of the pelvis going from a supine to a standing position, causing a small increase in the anteversion of the acetabular component from $19^{\circ}\left(4.6^{\circ} ; 10^{\circ}\right.$ to $\left.29^{\circ}\right)$ to $21^{\circ}\left(5.8^{\circ} ; 4^{\circ}\right.$ to $\left.31^{\circ}\right)[14,21]$.

On the other hand, besides searching with a quality measurement tool on ap pelvic plain radiographs, pelvic tilt is still an issue which can be addressed only in part intraoperatively. For example, intraoperative cup positioning is challenging, particularly in the lateral decubitus position with respect to the pelvic tilt. In the intraoperative setting and especially in computer-assisted THA, cup position is generally determined in reference to the APP [2]. Kanawade found that ante-inclination during sitting results in a more vertical acetabular cup, which can result in hip instability, especially drop-out dislocation, and edge-loading wear. Therefore, this dynamic approach is essential for activities such as walking or sitting. Patients with a hypermobile pelvis are especially at risk. It is the pelvic spatial position during postural change that creates the postoperative consequences of the surgical cup placement [22].

Moreover, Ross describes dynamic changes in pelvic tilt and its significant influence on the functional orientation of the acetabulum [23].

In our study we used a vector arithmetic measurement method to determine cup inclination and anteversion. However, postoperative CT scan-based methods are regarded as the most reliable methods for measuring postoperative cup orientation, but they carry the risks associated with additional radiation and added expense [6, 7]. Widmer reported a protractor for measuring the anteversion of acetabular cups on radiographs, but with limited precision and a substantial error range from $-16.6^{\circ}$ to $29.8^{\circ}$ [6]. Other studies reported that errors in measuring the cup position with various radiographic measurement methods could be high, exceeding 20 degrees, due to the wide variability in individual pelvic orientation relative to the radiographic film plate during image acquisition $[6,7,24,25]$. Similarly, estimating dynamic pelvic tilt intraoperatively is challenging. However, pelvic tilt has a major impact on cup positioning and postoperative function especially in the lateral decubitus position. Therefore, future concepts are encouraged to account for dynamic pelvic tilt.

When comparing our own data with the results in the literature, the accuracy of the radiographic vector arithmetic technique is 
Table 4 Reported validity of plain radiograph measurements compared with CT measurements for cup anteversion.

Tab. 4 Validität der Anteversionsmessungen im Röntgen von Beckenübersichtsnaufnahmen im Vergleich zu 3D-CT-Messungen.

\begin{tabular}{|c|c|c|c|c|c|c|}
\hline author & & $\begin{array}{l}\text { method for measuring } \\
\text { cup anteversion }\end{array}$ & definition & $\begin{array}{l}\text { referenced plane } \\
\text { of CT }\end{array}$ & $\begin{array}{l}\text { mean error in } \\
\text { degrees (SD) }\end{array}$ & range in degrees \\
\hline \multirow{2}{*}{$\begin{array}{l}\text { Hassan et al. } \\
\text { [1995] }\end{array}$} & \multirow[t]{2}{*}{$\mathrm{JOA}$} & Hassan's method & \multirow[t]{2}{*}{ not known } & \multirow[t]{2}{*}{ not known } & \multirow[t]{2}{*}{-2.5} & \multirow[t]{2}{*}{-0.8 to -3.4} \\
\hline & & AP radiographs & & & & \\
\hline \multirow{2}{*}{$\begin{array}{l}\text { Liaw et al. } \\
\text { [2005] }\end{array}$} & \multirow[t]{2}{*}{ CORR } & Liaw's method & \multirow{2}{*}{$\begin{array}{l}\text { radiographic } \\
\text { anteversion }\end{array}$} & \multirow[t]{2}{*}{ not known } & \multirow[t]{2}{*}{$1(0.7)$} & \multirow[t]{2}{*}{ Not known } \\
\hline & & AP radiographs & & & & \\
\hline \multirow{7}{*}{$\begin{array}{l}\text { Marx et al. } \\
{[2006]}\end{array}$} & \multirow[t]{7}{*}{ AOTS } & Mc Laren's method & \multirow{7}{*}{$\begin{array}{l}\text { radiographic } \\
\text { anteversion } \\
\text { (for all) }\end{array}$} & \multirow{7}{*}{$\begin{array}{l}\text { anatomic } \\
\text { APP } \\
\text { (for all) }\end{array}$} & $-14.5(10.5)$ & \multirow[t]{7}{*}{ not known } \\
\hline & & Ackland's method & & & $-14.3(10.3)$ & \\
\hline & & Pradhan's method & & & $-14.5(10.2)$ & \\
\hline & & Widmer's method & & & $-6.4(10.8)$ & \\
\hline & & Hassan's method & & & \multirow[t]{3}{*}{$-14.4(10.2)$} & \\
\hline & & AP radiographs & & & & \\
\hline & & (for all) & & & & \\
\hline $\begin{array}{l}\text { Ghelman et al. } \\
\text { [2009] }\end{array}$ & CORR & $\begin{array}{l}\text { Woo's method from } \\
\text { cross-table lateral } \\
\text { radiographs }\end{array}$ & $\begin{array}{l}\text { radiographic } \\
\text { anteversion }\end{array}$ & $\begin{array}{l}\text { radiographic } \\
\text { coronal plane }\end{array}$ & 8.7 & -10.7 to 25 \\
\hline \multirow{8}{*}{$\begin{array}{l}\text { NHO et al. } \\
{[2012]}\end{array}$} & \multirow[t]{8}{*}{ JBJS } & Lewinneck's method & \multirow{8}{*}{$\begin{array}{l}\text { anatomic } \\
\text { anteversion }\end{array}$} & \multirow{8}{*}{$\begin{array}{l}\text { radiographic } \\
\text { coronal plane }\end{array}$} & 0.10 & \multirow[t]{8}{*}{ not known } \\
\hline & & Widmer's method & & & 7.66 & \\
\hline & & Hassan's method & & & 0.69 & \\
\hline & & Ackland, Bourne and & & & 11.14 & \\
\hline & & Uhthoff's method & & & -1.68 & \\
\hline & & Woo and Morrey's & & & \multirow[t]{3}{*}{$-1,28$} & \\
\hline & & method & & & & \\
\hline & & $\begin{array}{l}\text { AP radiographs } \\
\text { (for all) }\end{array}$ & & & & \\
\hline \multirow{2}{*}{$\begin{array}{l}\text { LU et al. } \\
\text { [2013] }\end{array}$} & \multirow[t]{2}{*}{ CORR } & Lewinneck's method & \multirow{2}{*}{$\begin{array}{l}\text { radiographic } \\
\text { anteversion }\end{array}$} & \multirow{2}{*}{$\begin{array}{l}\text { radiographic } \\
\text { coronal plane }\end{array}$} & \multirow[t]{2}{*}{$0.55(3.14)$} & \multirow[t]{2}{*}{ not known } \\
\hline & & AP radiographs & & & & \\
\hline \multirow{4}{*}{$\begin{array}{l}\text { Craiovan et al. } \\
\text { [2014] }\end{array}$} & & $2 \mathrm{D} / 3 \mathrm{D}$ method & anatomic & anatomic & $-1.1(2.8)$ & -4.8 to 3.7 \\
\hline & Orthop. & AP radiographs & anteversion & app & & \\
\hline & & 2D/3 D method & anatomic & anatomic & $-0.7(2.1)$ & -5.5 to 3.1 \\
\hline & & AP radiographs & anteversion & APP & & \\
\hline current & & modiCAS||plan & radiographic & radiographic & $-0.8(7.9)$ & -27.6 to 22.1 \\
\hline study & & vector calculation & anteversion & coronal plane & & \\
\hline
\end{tabular}

comparable to Lewinnek's method [26]. Liaw's method, Woo and Morrey's method, McLaren's method, Ackland, Bourne and Uhthoff's method, Pradhan's method, Widmer's method and Hassan's method are less accurate ( $\bullet$ Table 4 ). However, some of the studies used the APP and some used the coronal plane as a reference plane for cup measurement. The placement of the cup may be in the safe zone by one definition but outside the safe zone by other definitions. It is therefore important to use the same reference plane (APP or coronal plane) when comparing component position after THA $[24,25,27]$. In this study, we found a good accuracy of the radiographic vector arithmetic cup measurement technique with a mean of under $2^{\circ}$ for inclination and under $1^{\circ}$ for anteversion when compared to a 3D-CT reconstruction model within the coronal plane. However, we also realized some outliers with a maximum difference of $17^{\circ}$ for inclination and $27^{\circ}$ for anteversion between the radiographic measurement and the CT measurement protocol. These outliers may be caused by three main phenomena: First, measurements on radiographs require good quality radiographs, which means a nearly perfect AP projection without rotation on the transverse and longitudinal axes, and centered at the hip. If the projection is not perfect, there will be measurement errors. Second, especially a bias in anteversion measurements using radiographs is common because a three-dimensional object is measured using two-dimensional image projection. Therefore, special regard must be given to different physiological orientations, static, vertical and rotational alignment and to the orientation of the radiographic plate. Third, previous studies have pointed out that antero-posterior pelvic tilt is the factor that introduces uncertainty in measuring the orientation of the cup when comparing conventional radiographs with CT scans after THA. With anterior pelvic tilt, less anteversion of the acetabulum will be measured radiographically and with posterior pelvic tilt, increased anteversion of the acetabulum will be measured radiographically $[28,29]$. In this study, we measured a posterior pelvic tilt $>10^{\circ}$ in $11.4 \%$ ( 14 of 123 patients), which is consistent with other studies [14, 30]. Lembeck et al. [29] concluded that every degree of pelvic tilt influences implant anteversion by $0.7^{\circ}$. Thus, a $10^{\circ}$ reduction in pelvic tilt can increase acetabular component anteversion by $7^{\circ}$. Therefore, pelvic tilt strongly influences functional cup position measurements. Additionally, the change of pelvic tilt between supine and standing positions further complicates correct cup estimation [21]. We realized that the largest anteversion measurement errors of $>10^{\circ}$ between $3 \mathrm{D}-\mathrm{CT}$ and radiographs were associated with an extraordinary pelvic tilt larger than $10^{\circ}$. Pelvic tilt is therefore the main reason for measurement uncertainty of the acetabular cup on radiographs with regard to the coronal plain.

In conclusion, our data demonstrates that a vector arithmetic radiological method for measuring acetabular cup orientation on antero-posterior radiographs of the hip after THA needs a correct postoperative view with special regard to the pelvic tilt to be a valid quality measurement tool. CT remains, however, the gold 
standard for accurately determining acetabular cup position when a lower tolerance limit $(+/-3$ degrees) is required for a more complex biomechanical evaluation. Future developments for measuring cup orientation on ap plain pelvic radiographs of the hip should account for integration of pelvic tilt in order to maximize measurement accuracy.

\section{Clinical relevance}

1. The vector arithmetic radiological method for measuring acetabular cup orientation on antero-posterior radiographs of the hip after THA is a helpful procedure to measure cup inclination and anteversion in everyday clinical practice as a first-line imaging modality.

2. CT remains the gold standard for accurately determining acetabular cup position.

3. Future measuring on radiographs for cup orientation after THA should account for integration of the pelvic tilt in order to maximize the measurement accuracy.

\section{References}

1 Leichtle U, Gosselke N, Wirth C et al. Radiologische Evaluation der Variationsbreite der Pfannenpositionierung bei konventioneller Hüftendoprothesenversorgung. RöFo - Fortschritte Auf Dem Geb Röntgenstrahlen Bildgeb Verfahr 2007; 179: 46-52

2 Renkawitz T, Haimerl M, Dohmen L et al. Minimally invasive computernavigated total hip arthroplasty, following the concept of femur first and combined anteversion: design of a blinded randomized controlled trial. BMC Musculoskelet Disord 2011; 12: 192

3 Eckardt A, Karbowski A, Schwitalle $M$ et al. Messung der Pfannenwanderung bei zementfreien Hüftimplantaten. RöFo - Fortschritte Auf Dem Geb Röntgenstrahlen Bildgeb Verfahr 1998; 169: 146-151

4 Lewinnek GE, Lewis JL, Tarr R et al. Dislocations after total hip-replacement arthroplasties. J Bone Joint Surg Am 1978; 60: 217-220

5 Hube R, Dienst $M$, von Roth P. Complications after minimally invasive total hip arthroplasty. Orthop 2014; 43: 47-53

6 Kalteis T, Handel M, Herold T et al. Position of the acetabular cup - accuracy of radiographic calculation compared to CT-based measurement. Eur J Radiol 2006; 58: 294 - 300

7 Marx A, von Knoch M, Pförtner J et al. Misinterpretation of cup anteversion in total hip arthroplasty using planar radiography. Arch Orthop Trauma Surg 2006; 126: 487-492

8 Tannast M, Zheng G, Anderegg $C$ et al. Tilt and rotation correction of acetabular version on pelvic radiographs. Clin Orthop 2005; 438: $182-190$

9 Pradhan R. Planar anteversion of the acetabular cup as determined from plain anteroposterior radiographs. J Bone Joint Surg Br 1999; 81: $431-435$

10 Widmer KH. A simplified method to determine acetabular cup anteversion from plain radiographs. J Arthroplasty 2004; 19: 387-390

11 Murray DW. The definition and measurement of acetabular orientation. J Bone Joint Surg Br 1993; 75: 228-232
12 DiGioia AM, Hafez MA, Jaramaz B et al. Functional pelvic orientation measured from lateral standing and sitting radiographs. Clin Orthop 2006; 453: $272-276$

13 Kalteis T, Handel M, Bäthis $H$ et al. Imageless navigation for insertion of the acetabular component in total hip arthroplasty: is it as accurate as CT-based navigation? J Bone Joint Surg Br 2006; 88: 163 - 167

14 Babisch JW, Layher F, Amiot LP. The rationale for tilt-adjusted acetabular cup navigation. J Bone Joint Surg Am 2008; 90: 357-365

15 Renkawitz T, Weber M, Springorum HR et al. Impingement-free range of movement, acetabular component cover and early clinical results comparing 'femur-first' navigation and 'conventional' minimally invasive total hip arthroplasty. Bone Jt J 2015, in press. 97

16 Harrison CL, Thomson AI, Cutts $S$ et al. Research synthesis of recommended acetabular cup orientations for total hip arthroplasty. J Arthroplasty 2014; 29: 377-382

17 Wan Z, Malik A, Jaramaz B et al. Imaging and Navigation Measurement of Acetabular Component Position in THA. Clin Orthop 2008; 467: 32 42

18 Nho JH, Lee YK, Kim HJ et al. Reliability and validity of measuring version of the acetabular component. J Bone Joint Surg Br 2012; 94-B: $32-36$

19 Bland JM, Altman DG. Measurement error and correlation coefficients. BMJ 1996; 313: $41-42$

20 Ottersbach A, Haaker R. Optimization of cup positioning in THA-comparison between conventional mechanical instrumentation and computer-assisted implanted cups by using the orthopilot navigation system. Z Für Orthop Ihre Grenzgeb 2005; 143: 611-615

21 Eilander W, Harris SJ, Henkus HE et al. Functional acetabular component position with supine total hip replacement. Bone Jt J 2013; 95-B: $1326-1331$

22 Kanawade V, Dorr LD, Wan Z. Predictability of Acetabular Component Angular Change with Postural Shift from Standing to Sitting Position. J Bone Jt Surg 2014; 96: 978-986

23 Ross JR, Nepple JJ, Philippon MJ et al. Effect of changes in pelvic tilt on range of motion to impingement and radiographic parameters of acetabular morphologic characteristics. Am J Sports Med 2014; 42: 2402 2409

24 Zheng G, Zhang X. Computer assisted determination of acetabular cup orientation using 2D-3D image registration. Int J Comput Assist Radiol Surg 2010; 5: 437-447

25 Steppacher SD, Tannast $M$, Zheng $G$ et al. Validation of a new method for determination of cup orientation in THA. J Orthop Res Off Publ Orthop Res Soc 2009; 27: $1583-1588$

$26 \mathrm{Lu} \mathrm{M}$, Zhou YX, Du H et al. Reliability and validity of measuring acetabular component orientation by plain anteroposterior radiographs. Clin Orthop 2013; 471: 2987-2994

27 Craiovan B, Renkawitz T, Weber $M$ et al. Is the acetabular cup orientation after total hip arthroplasty on a two dimension or three dimension model accurate? Int Orthop 2014; 38: 2009-2015

28 Anda S, Svenningsen S, Grontvedt T et al. Pelvic inclination and spatial orientation of the acetabulum. A radiographic, computed tomographic and clinical investigation. Acta Radiol Stockh Swed 1987 1990; 31: 389-394

29 Lembeck B, Mueller O, Reize P et al. Pelvic tilt makes acetabular cup navigation inaccurate. Acta Orthop 2005; 76: 517-523

30 Nishihara S, Sugano N, Nishii T et al. Measurements of pelvic flexion angle using three-dimensional computed tomography. Clin Orthop 2003: $140-151$ 